\title{
Apparatets sammenbrud
}

\section{"I straffekolonien" med Franz Kafka}

\section{"I straffekolonien" som cæsur og samtidstolkning}

I artiklen “"unsere allgemeine und meine besondere Zeit”. Autobiographie und Zeitgenossenschaft in Kafkas Schreiben", oprindeligt fra 1983, antager Jost Schillemeit ${ }^{\mathrm{T}}$ korrekt en 'cæsur' i forfatterskabet sidst i 1916. Derimod antager han ukorrekt, at der i forfatterskabet før cæsuren ikke findes '“udsagn' om hans egen tid som sådan, til forskel fra andre tider, ikke 'tydninger' af hans egen tid eller hans egen 'tidsalder', og det lige så lidt i de personlige vidnesbyrd, brevene og dagbøgerne, som i de litterære tekster. [I stedet dominerer her] et selvbiografisk grundtræk, der tydeligt kan erkendes, om end det er svært at definere nøjagtigt" (Schillemeit 2004: 227, min oversættelse). ${ }^{2}$ Som et af sine hovedbelæg anfører han det kendte dagbogsnotat af 15. oktober 1914, efter den 14 dages ferie, hvor Kafka skrev "Naturteatret fra Oklahoma" og "I straffekolonien": "Fjorten dags godt arbejde, til dels fuldstændig begribelse af min situation." (Kafka 1995, VIII: 319, m. o.).

Jeg er uenig i denne tolkning og vil fremlægge en anden i nærværende artikel. Men faktisk modsiger Schillemeit den og sig selv i en senere artikel: "Franz Kafka: Werk - Nachlass - Edition. Versuch eines Überblicks" (1991/93). Her antager Schillemeit - uden for alvor at ændre opfattelse af forfatterskabets forløb - en yderligere 'cæsur' i og med tilblivelsen af "I straffekolonien" i de 14 dages ferie, Kafka tog i oktober 1914:

46 for med denne fortælling gik Kafka over til en ny fortælleform, forskellig fra alle hans tidligere tekster: en lignelsesagtig-allegorisk, dobbeltbundet fortælleform, hvori de fortalte forløb ud over sig selv oveni betyder "noget andet", nemlig noget, der har med forfatterens samlede åndelige og sjælelige "situation" at gøre og er bestemt til at afklare den. (Schillemeit 2004: 357, m. o.)

Efter igen at have henvist til Kafkas ovenfor anførte bemærkning om sin "situation", som Schillemeit altså nu må tolke anderledes, hævder han, at den nye skrivemåde 
influerer de dele af Processen, som er opstået herefter, bl.a. samtalen med Titorelli og parablen "Foran loven". Hvorledes Schillemeit opfatter "I straffekolonien" som et billede på autors 'samlede situation', fremgår imidlertid ikke, for han giver ingen som helst tolkning af den.

I nærværende artikel vil jeg fremlægge en indgående læsning af "I straffekolonien”, der på flere andre planer, end Kafka-forskningen efter mit kendskab hidtil har haft blik for, kan vise, hvorledes denne fortælling repræsenterer noget afg $\varnothing$ rende nyt i forfatterskabet. Efter en indkredsning af fortællingens genremæssige, tematiske, stilistiske og kronotopiske grundtræk lægger jeg vejen omkring nogle væsentlige kontekster, personlige, litterære og historiske. Det naturlige udgangspunkt er Kafkas dagbøger ${ }^{3}$ fra perioden omkring tilblivelsen af "I straffekolonien". Herefter følger en kortlægning af nogle af de vigtigste eksempler på specifik litterær intertekstualitet - Octave Mirbeau, Fjodor Dostojevskij og Det nye Testamentes beretninger om Jesu lidelseshistorie. I den videre analyse indlæses fortællingens samfundsbillede i konkrete historiske kontekster. ${ }^{4}$

\section{Værdidebat - over forståelseskløfter}

"I straffekolonien" foregår på en tropeø, der af en kolonimagt er indrettet til straffekoloni. Handlingen udspiller sig omkring et "ejendommeligt apparat" og beretter om den sidste, på flere måder mislykkede henrettelse, der finder sted i dette og medfører eller i det mindste ledsages af apparatets sammenbrud. Handlingen involverer tre hovedpersoner: den forskningsrejsende på besøg; officeren, der forestår henrettelsen, og som undervejs forsøger at forklare den rejsende den samfundsmæssige og juridiske orden, hvor den har en central betydning; og den dømte, offeret for den tiltænkte henrettelse.

En skildring af fangeøens gamle og nye orden er indfældet i en spændt værdidebat, en problematisk dialog mellem ideologer, der står hinanden fjernt, nemlig officeren og den forskningsrejsende. Den dømte forstår ikke meget af det hele, hverken af apparatet eller af samtalen, der foregår på det for ham uforståelige sprog fransk, skønt samtalen har indgribende betydning for hans skæbne. Med den menige soldat, der skal holde styr på ham og bistå under henrettelsen, pludrer han derimod lystigt løs på deres fælles sprog, som den rejsende til gengæld ikke forstår.

I modsætning til fangen og soldaten er den rejsende og officeren bevidste ideologer, repræsenterer hele kulturer og værdier, samfunds-, rets- og moralopfattelser. Gennem kombinationen af træk som filosofisk dialog om samfunds- og retssystemer, fokus på en konfrontation om livets 'sidste, afgørende spørgsmål', allegorisk tingsbeskrivelse og hele skildringens sigte på universalitet (samfundet koncentreret til en fange $\varnothing$ ) placerer fortællingen sig genremæssigt - trods sin korthed - som en grundform af anatomien, den menippæiske satire. ${ }^{5}$

Officerens fremvisning af maskinen og stadigt mere appellerende henvendelse til den forskningsrejsende viser sig gradvist at være en sidste desperat apologi, en sand forsvarstale for en døende orden, som han er alene tilbage om at repræsentere åbent og helhjertet. Hans manende, til sidst tryglende overbevisningsfors $ø$ g er imidlertid en eklatant fejlkalkulation, især da hans evne til at indleve sig i den forsk- 
ningsrejsendes forudsætninger er tragikomisk begrænset af den selvcentrering, som hans fanatiske entusiasme hilder ham i. I overensstemmelse med sin kulturs grundsyn - "Skylden er altid ubetvivlelig" (2008a: 132) - er han selv uden evne til tvivl om den gamle ordens værdier. Men nederlaget i form af denne ordens tab af legitimitet kan han erkende.

Komplementært til officeren repræsenterer den forskningsrejsende den moderne kritiske ånd, den systematiske tvivl, Descartes ophøjede til princip. Han er 'betænkelig' ved at gribe ind og tvivler hele vejen igennem på, hvilken rolle han skal spille. Ikke desto mindre står der to gange "ubetvivlelig" på hans vegne: "Procedurens uretfærdighed og eksekutionens umenneskelighed var ubevivlelig" (2008a: 137). "Det svar som han måtte give, havde lige fra begyndelsen været ubetvivleligt for den rejsende" (2008a: 144). Dette til trods for at han forsikrer officeren om, at "Deres ærlige overbevisning er gået mig nær, selvom den dog ikke kan vildlede mig." (ibid.). Forinden er hans værdier blevet bekræftet af fortællerstemmen, i mine ører dog med en parodisk overtone: "han var i grunden ærlig og frygtede ikke noget. Alligevel tøvede han nu et åndedrags tid ved synet af soldaten og den dømte. Men til sidst sagde han, sådan som han måtte: "Nej"”' (ibid.). Det får mærkbare følger: "Så er tiden altså inde" (2008a: 145), udbryder officeren.

Det er svært for den rejsende at forstå officerens tankebaner, men endnu vanskeligere har han ved at sætte sig ind i den dømtes og soldatens verden. De fremstår som klovner i et komisk sub-plot, der spiller deres egne små pantomimiske farcer under den høje idedebat på fransk (omsat til tysk). Den indfødte tjener er dømt for en spontan oprørshandling, der er tegnet med dyriske og kannibalistiske træk: "Kast pisken væk, eller jeg æder dig" (2008a: 132). I henrettelsessituationen viser han en anden side som føjelig og 'hundsk hengiven', men er dog i det små hele tiden udisciplineret og besværlig. Først til sidst, da han selv er fri, og officeren er ved at tage hans sted, forstår han, at noget væsentligt er ved at ske:

16 Navnlig den dømte syntes at have fået en anelse om en eller anden stor omvæltning. Det der var sket for ham, skete nu for officeren. [...] Det var altså hævn. Uden selv at have lidt til det sidste ville han blive hævnet til det sidste. Et bredt, lydløst grin kom nu til syne på hans ansigt og forsvandt ikke igen. (2008a: 147)

Men så snart han er af med officeren, søger han (med sin ven soldaten) en ny autoritet og frelserskikkelse i den rejsende.

\section{Krisetiden og øen som (u)sted}

Idedebatten er vehikel i en overgang, hvor hævdvundne autoriteter og dertil svarende faste roller bliver flydende og skifter plads - uden at falde på plads. "Jetzt ist alles fertig!" (1995, II: 151), udbryder officeren ved fortællingens begyndelse. Den efterfølgende handling giver sætningen en tvetydighed, der ikke kommer til sin ret i Isak Winkel Holms oftest rammende oversættelse: "Nu er alt klart!" (2008a: 127). Gennem bibetydningen 'Nu er alt forbi / Nu er det sket med alt (det gamle)' udtrykker den uskyldige sætning en foregribelse af sammenbruddet. Modsat fyldes 
en stor del af fortællingen ud af officerens suggestive tilbagegreb til den gamle kommandants tid, hvor henrettelser samlede hele kolonien, og hvor den martredes forklarede, forløsende tydning af dommens skrift på sin krop udgjorde epokens åndelige centrum: "Hvilke tider, min kammerat!" (2008a: 139), som officeren udbryder, mens han lidet passende omfavner den fremmede gæst. "Det er en skam, at de ikke har kendt den tidligere kommandant!" udbryder han tidligere i samtalen, men kan endnu trøste sig ved kommandantens konkrete spor i nutiden, nemlig i apparatet: ““" - Men”, afbrød officeren sig selv, "jeg snakker og hans apparat står her foran os."' (2008a:128).

Handlingens nutid forløber over få timer, hvori der imidlertid er koncentreret et helt verdenshistorisk forløb. Ved begyndelsen står apparatet i centrum, men det bliver stadigt tydeligere, at maskinen allerede er ved at blive marginaliseret. De slidte hjul synger på sidste vers før sammenbruddet. Nu er der andre tider i kolonien, hvis ledelse ikke prioriterer forløsende pinsler, men knaldhårdt arbejde med udbygning af infrastrukturen: "havnebyggeri, evig og altid havnebyggeri!" (2008a: 143).

Havne bygger man ved kysten, og hvis der er kyst hele vejen rundt - hvis stedet kort sagt er en $\varnothing$ - er havne særligt vigtige. En $\varnothing$ er litterært set et passende sted, hvis man vil isolere og koncentrere en konflikt, hvis man vil fremmedgøre og kondensere billedet af et samfund. ${ }^{6} \varnothing$ en er et foretrukket sted i utopisk litteratur fra Thomas More over Jules Verne til Aldous Huxley (hvis man ikke vælger et lignende fremmed og isoleret sted som et underjordisk rige eller en fremmed planet), i myriader af robinsonader og i satirisk litteratur fra Holberg til Swift. Et ø-samfund må desuden perciperes gennem en tilrejsendes fremmede, forskende blik.

Ligesom en $\varnothing$ ofte er stedet for utopiske eller satiriske skildringer (og den hyppige blanding af dem), kan både utopier og satirer betjene sig af en kompleks genstand, en monstrøs bygning eller en megamaskine, som tingsligt symbol, det centrale billede på en kultur, et samfund. Øer er, ligesom maskiner, ejendommelige litterære apparater for samfundsskildringer, der på en og samme gang er fremmedgjorte, forskudte, og rummer ambitionen om et helhedsbillede, en allegori over en hel kultur - eller en dramatisk parabel om en kulturs skæbnesvangre undergang og de lige så forjættende som skrækindjagende varsler, den nye bærer i sig.

\section{Kafkas dagbøger - den brudte forlovelse og den udbrudte krig}

Flere betydningsniveauer i den forskudte og fremmedgjorte fremstilling, som i dette tilfælde måske blev ekstra mærkværdiggjort af hensyn til krigstidscensuren, vil jeg som nævnt udfolde under nødvendige omveje gennem personlige, litterære og historiske kontekster.

Kafkas fyldige dagbogsnotater fra 1914, med særligt henblik på de syv-otte måneder fra sidst i maj og året ud, er emnemæssigt vidtspændende. Som det ligger i dagbogsgenren, er der også hos Kafka vægt på den personlige refleksion og de intime relationer. Desuden er der - som vanligt i forfatteres dagbøger - omhyggelige registreringer af hans læsning, refleksioner over andre forfattere, overvejelser over hans egen litterære virksomhed og egentlige litterære udkast. En dagbog er ikke noget sikkert bevis for eller imod, hvad der uden for dagbogen optager den 
skrivende. Men det er dog bemærkelsesværdigt, hvor meget det samfundsmæssige fylder i denne periode, både absolut og relativt til andre dele af Kafkas dagbøger.

På det intimt personlige plan er der mange optegnelser, som er gennemsyret af Kafkas forviklede følelser omkring de dramatiske svingninger i forholdet til Felice Bauer. Den 30.5.1914 fandt den officielle deklarering af forlovelsen med Felice sted i Berlin. Kafka gik straks i panik og følte sig ifølge notat af 6.6. "bundet som en forbryder" (Kafka 1991: 101). Den 11.6. begynder han en fortælling om forlokkelse: "Forlokkelse i landsbyen". Den 5.7. udbryder han fortvivlet: "At måtte bære og forårsage sådanne lidelser" (Kafka 1991: 105). Den 11.7. rejser han til Berlin. Næste morgen sættes han på anklagebænken. Efter pinlige og berettigede anklager ophæves forlovelsen igen. Det mindes han i notat af 23.7. som "Domstolen på hotellet" (ibid.), en scene, der er et utroligt koncentrat af pinagtige, sansede detaljer, herunder larm fra gården som fra en maskinfabrik. Blandingen af smerte, skyldfølelse og lettelse følger ham resten af året.

Samfundsforhold optager ham både i form af almene overvejelser og reaktioner på mobiliseringen, udbruddet af verdenskrigen og krigens gang. 12.6. reflekterede Kafka således over sammenhængen i samfundet eller manglen på samme:

6f Det samfundsmæssige liv foregår i cirkler. Kun de, der er ramt af bestemte lidelser, forstår hinanden. De danner i kraft af deres lidelses natur en kreds og understøtter hinanden. [...] Men en erkendelse af deres situation viser sig først, når de i fællesskab sænker hovederne, og den fælles hammer rammer ned på dem. (Kafka 1995, VIII: 293f.)

Efter forlovelsens ophævelse i Berlin rejste Kafka videre på ferie til Lübeck og til det danske badested Marielyst på Falster. Her opholdt han sig, da Østrig den 23.7. (efter mordet på det habsburgske tronfølgerpar i Sarajevo den 28.6.1914) stillede Serbien over for det ultimatum, der udløste Første Verdenskrig. Tre dage senere rejste Kafka tilbage over Berlin, hvor han fik lejlighed til modvilligt at beundre effektiviteten i de tyske krigsforberedelser.

Umiddelbart efter hans hjemkomst til Prag den 28.7. erklærer Østrig Serbien krig. 29.7. nævnes navnet Josef K. første gang i dagbogen. 31.7. skriver han: “Jeg har ingen tid. Der er almindelig mobilisering. [Den gælder dog ikke ham, han er fritaget som 'uundværlig', men han har blandede følelser ved det; desuden hænger han på ansvaret for sin indkaldte svogers fabrik] Men trods alt det vil jeg skrive, ubetinget, det er min kamp for at overleve" (Kafka 1991: 111). Den 2. august kommer den berømte indføring i dagbogen: "Tyskland har erklæret Rusland krig. - Eftermiddag til svømning ["Schwimmschule"]" (Ibid.). Den sammenstilling er blevet set som udtryk for en total ligegyldighed fra Kafkas side over for krigen og det omgivende samfund i det hele taget. Tolkningen er uden belæg i dagbogen og i resten af Kafkas aktiviteter. Den 6. august skriver han således: "Jeg opdager intet andet i mig selv end smålighed og ubeslutsomhed, misundelse og had mod de kæmpende som jeg lidenskabeligt ønsker alt ondt" (Kafka 1991: 112). Kritik, en følelse af at stå udenfor, ja, men også lidenskabelig optagethed. Derefter følger en af Kafkas centrale refleksioner over sit forhold til litteraturen, hvor han bl.a. bemærker: "Trangen til at fremstille mit drømmeagtige indre liv har skubbet alt andet til side som noget uvæ- 
sentligt, og det vantrives derfor på en skrækkelig måde og bliver ved med at vantrives. Intet andet kan nogensinde stille mig tilfreds" (ibid.). Det betyder ikke, at han lukker øjnene. På samme dato beskriver han kritisk oppiskningen af patriotismen: "Patriotisk demonstration. Tale af borgmesteren som forsvandt og kom frem igen, og det tyske råb: "Vores elskede monark længe leve, hurra! Jeg står og ser til med mit arrige blik. Disse demonstrationer er et af krigens modbydeligste ledsagefænomener" (ibid.f.).

Så begynder han at skrive og afgørende bliver det spørgsmål, om det går fremad eller står stille med skriveriet. 3.9. reflekterer han over det højst tvetydige forhold mellem skriveriet og krigen: "Igen knap to sider. Først mente jeg at min bedrøvelse over de østrigske nederlag og angsten for fremtiden (en angst der i grunden synes mig både latterlig og infam) overhovedet ville hindre mig i at skrive" (Kafka 1991: 114). Han afviser det først, men mener alligevel, at hans private sorger over bruddet med Felice og sorgen over krigen er intimt forbundne: "De tanker der er knyttet til krigen er ved den plagsomme måde på hvilken de flænser i mig fra de forskelligste retninger, meget lig de gamle bekymringer omkring F." (ibid.).

I begyndelsen af oktober 1914 tager Kafka to ugers ferie for at fordybe sig i arbejdet med Processen. I stedet skriver han som nævnt "Naturteatret fra Oklahoma" (slutkapitlet i hans Amerika-roman Den bortkomne, som dog stadig forblev uafsluttet) samt "I straffekolonien". 15.10. ytrer han i dagbogen en usædvanlig tilfredshed med sit arbejde: "Fjorten dages godt arbejde, til dels fuldstændig begribelse af min situation" (Kafka 1995, VIII: 319).7 Kort efter læser han "I straffekolonien" op for sine litterære venner ved en sammenkomst hos Franz Werfel, jf. dagbogsnotat af 2.12.: "I eftermiddags hos Werfel med Max [Brod] og [Otto] Pick. Læste "I straffekolonien", ikke ganske utilfreds, selv ikke over de overtydelige, uudviskelige fejl" (Kafka 1995, VIII: 323). Som et resultat af dagen pålægger han sig ubetinget at arbejde videre. At hans indre drømmeverden fortsat er invaderet af det offentlige og politiske, ser man i slutningen af notatet: "Drøm i nat. Hos kejser Wilhelm. I slottet. Den skønne udsigt” (Kafka 1995, VIII: 325).

Under udgivelsen af "I straffekolonien" uddybede Kafka denne sammenhæng mellem sin oplevelse af det personlige og af dybe tendenser i samtiden i et brev af 11.10.1916 til forlæggeren Kurt Wolff:

Uf Til forklaring af denne sidste fortælling tilføjer jeg blot, at det ikke kun er den, der er pinefuld, men at vor tid i almindelighed og min i særdeleshed har været og er yderst pinefuld, og min egen har endda været pinefuld endnu længere end den almene. (Heller \& Beug (red.) 1969: 83, m. o.)

\section{Mirbeau, Dostojevskij og Bibelen}

En af de vigtigste litterære inspirationskilder til "I straffekolonien" er romanen Le Jardin des supplices (Straffenes have, 1899, tysk oversættelse 1901, hvoraf passager straks blev forbudt) af den franske journalist og forfatter Octave Mirbeau (18481917). Læsning af Mirbeaus skandaleværk er ikke nævnt i dagbogen. Højst ligger der i et af de litterære udkast, den lange 'russiske' fortælling af 15. august, "Erin- 
dring om Kaldabanen", med temaet om kampen mod rotter en indforstået henvisning til en af de mest modbydelige af de mange udsøgt grusomme torturmetoder, der skildres i Le Jardin des supplices.

Octave Mirbeau var en kritisk-anarkistisk intellektuel, forsvarede med stor skarphed Alfred Dreyfus og provokerede bl.a. med romaner som den ovennævnte og Journal d'une femme de chambre (En kammerpiges dagbog, 1900, filmatiseret både af Renoir og Buñuel). Sporene fra den stærkt de Sade-prægede roman blev først påvist af W. Burns (Burns 1957). Forbindelsen er videre dokumenteret i Wagenbach 1975 og yderligere udbygget i Binders Kafka-Kommentar, der er yderst grundig - og ret ensidigt hæfter sig ved forholdet til Mirbeau.

Le Jardin des supplices åbner med en dedikation: "Til præsterne, til soldaterne, til dommerne, / til de mennesker, / som opdrager, leder, regerer menneskene / dedicerer jeg / disse sider af mord og blod." I Vincenzo Ruggieros Crime in Literature, hvor romanen behandles i kapitlet "Hugo, Mirbeau and Imprisonment", sammenfattes sigtet med denne 'ufordøjelige' bog således: "Hans formål er at udstille magthavernes og hele samfundets hyklerier ved at vise, hvor mange af de institutioner og sædvaner, der almindeligvis tages for givet og endog betragtes som civilisationens søjler, der faktisk er grusomme og frastødende" (Ruggiero 2003: 208f., m.o.). Ubetvivleligt har Kafka været fascineret af Mirbeaus fornyelse af de Sade-traditionen. Den har været en vigtig inspiration for den udvikling af en rabiat, fremmedgjort samfundskritik med totalsigte, som finder sted med "I straffekolonien".

Ud over dette almene sigte vil jeg ud fra min egen læsning af Mirbeaus virkeligt ubehagelige bog fremhæve Kafkas kreative genbrug af et raffineret retorisk greb. Et 'højdepunkt' i fortællerens og hans depraverede engelske venindes bes $\varnothing$ g i den kinesiske tortur-have er en længere samtale med en traditionsbevidst og fagstolt torturbøddel, der beklager sig over tidernes ugunst og de gamle dyders forfald. De engelske imperialister - der er et hovedmål for bogens satire - udnytter deres formidable muligheder ringe, konstaterer torturmesteren misbilligende: “- På straffenes område, som på alle andre, er englænderne ikke kunstnere ... Alle de kvaliteter, De vil, mylady, men ikke den ... nej, nej, nej" (Mirbeau 1929: 180, m. o.). Kunsten at slå ihjel bør ikke måles i kvantiteten, men i den kvalitative evne til at påføre lidelser, i torturens frygtindgydende kunst. Det vestlige snobberi, der nu oversvømmer verden - de moderne våben, elektriciteten, sprængstofferne osv. - "alt det, der gør døden kollektiv, administrativ og bureaukratisk... altså alle Deres fremskridts uhumskheder... ødelægger lidt efter lidt de smukke traditioner fra vores fortid..." (Mirbeau 1929: 181). Kun i Straffenes have holdes traditionen endnu i hævd. Men hvor længe endnu? Med en selvforelsket dvælen ved detaljerne godtgør han sit mesterskab i at påføre lidelser. Men påskønnes en torturens virtuos som han i vore dage, får han avancement? Nej, dommerne har ringe sans for det og kommer med alle mulige indvendinger: "At vende tilbage til den klassiske tradition skræmmer dem... [...] Alt dette er karakteristiske symptomer på vores forfald... Åh, vi er et fortabt folk, et dødt folk! Japanerne kan komme... vi er ikke mere i stand til at modstå dem... Farvel, Kina!..." (Mirbeau 1929: 187).

Netop således, som heltemodig forsvarer af klassiske dyder, desværre nok en tabt sag, taler hos Kafka officeren til den rejsende. Desuden har Kafka - ligesom 
Mirbeau har forlagt billedet på civilisationens grusomhed til en provins i Kina under strategisk hensyntagen til krigens ophidsede patriotiske atmosfære kunnet bruge henlæggelsen af fortællingens sted til 'fjendens land', til en fjern, formentlig fransk djævleø, som et godt og effektivt fremmedgørelses-greb. Som anført af Klaus Wagenbach havde Kafka interesseret sig for deportationen af de franske kommunarder til en $\varnothing$ i Ny Kaledonien samt for Dreyfus' deportation til Djævleøen. Om apparatet bemærker Hartmut Binder dog i sin kommentar: "Den af Kafka beskrevne maskine har intet direkte forbillede hos Mirbeau" (Binder 1975: 177, m.o.).

En anden, mindst lige så vigtig litterær relation er besynderligt upåagtet i forbindelse med "I straffekolonien". Jeg griber tilbage til Kafkas dagbøger, hvor notaterne om hans løbende læsning som nævnt udgør et hovedspor. Dostojevskij er uden sammenligning den forfatter, som der er de fleste og fyldigste henvisninger til, og må i den givne periode antages at have udgjort hans vigtigste læsning.

Det begynder allerede den 15.3.; "Bag Dostojewskis kiste ville studenterne bære hans fangelænker. Han døde i et arbejderkvarter i en lejlighed på fjerde sal” (Kafka 1991: 95). Den 29.5., umiddelbart før han skal til Berlin og afgøre forholdet til Felice, får han et syn af sine 'planer' i et imaginært kalejdoskop: en grotesk vision af et optog med karnevalsvogn, småfolk, nøgne piger og roser. Scenen overtages dog af behornede smådjævle, og selv synker han lodret ned "gennem en skakt, der nøjagtig har min krops diameter, men en endeløs dybde" (Kafka 1995, VIII: 280). Samme dag noterer han "Dostojevskijs brev til broderen om livet i tugthuset" (Ibid.).

12.6. nævner han sin læsning af et brev fra Dostojevskij til en malerinde - efterfulgt af den ovenfor citerede refleksion over samfundslivets lukkede kredse. 1. 11. beretter han: "I dag delvis en skøn søndag. Læste i det Chotekske anlæg Dostojevskijs forsvarsskrift. [...] - Megen selvtilfredshed hele dagen igennem." (Kafka 1995, VIII: 321). 20.12. diskuterer han i dagbogen (videre) med Max Brod om Dostojevskijs karakteriseringsmetode: "Max' indvending mod Dostojewski at han lader for mange sindssyge optræde. Fuldstændig forkert” (Kafka 1991: 119). Herefter følger en indtrængende karakteristik af Dostojevskijs måde at skildre mennesker på.

I relation til "I straffekolonien" vil jeg argumentere for, at henvisningen til Dostojevskijs brev til broderen om livet i tugthuset er den mest interessante. Brevet er dateret Omsk, 22. februar 1854, og skrevet en uge efter Dostojevskijs frigivelse fra tugthuset. Det beretter om den frygtelige transport til Sibirien og giver det første fors $\varnothing g$ på at skildre selve rædslerne under opholdet i tugthuset, foregriber således Optegnelser fra Det døde hus. I brevet vil jeg først og fremmest hæfte mig ved den pinlige skæbnens ironi, at den grusomste bøddel for de intellektuelle politiske fanger, der havde sat livet ind for 'folkets' sag, var det selv samme folk, repræsenteret af de kriminelle straffefanger, og at ingen dialog var mulig:

4 Deres had mod de adelige overstiger alle grænser, og derfor modtog de os med åbent fjendskab og glædede sig over vor ulykke. Dersom vi havde vist os i mindste måde eftergivende, havde de ædt os med hud og hår. "I adelsfolk, I sylenæb, nu har I hakket nok i vort kød. Før var I herrer, I hundsede folket - men nu må I søbe af fadet med den ringeste af os, nu må I være brødre med os!" Dette tema summede i vore øren uden ophør i alle de fire år. To hundrede fjender blev ikke træt af at forfølge os, det var dem en fryd, en kostelig 
adspredelse. Det eneste, vi kunne gøre for at beskytte os mod det værste, var at vise dem ligegyldighed. Og så havde vi bevidstheden om vor moralske overlegenhed; den mærkede de, og den måtte de trods alt respektere. Fremfor alt gik det ikke an at føje sig det mindste efter dem. At vi stod over dem, følte de meget vel. Noget klart begreb om vor forbrydelse havde de ikke. Vi selv tav stille om den ting, og således var enhver mulighed for gensidig forståelse udelukket. Al deres hævntørst mod adelen måtte vi lade gå over vore hoveder. Vort liv var tungt. De politiske fanger havde det langt værre end kriminalforbryderne. (Dostojevskij 1966, 23: 79f.)

I samme brev skildrer Dostojevskij ganske vist også - næsten selvmodsigende - et andet forhold til 'folket': "Dog, til syvende og sidst er menneskene overalt mennesker. Under disse fire års tugthus har jeg mellem røvere og mordere fundet ægte mennesker" (Dostojevskij 1966, 23: 83). For "I straffekolonien" er det afgørende imidlertid, som jeg vil sandsynliggøre, den første erfaring og tolkning, som også udfoldes videre i Optegnelser fra Det døde hus, kapitel VII og VIII. Dostojevskij-sporet er i denne sammenhæng uudforsket. ${ }^{8}$

Endnu en overset intertekstuel relation er der mellem "I straffekolonien" og Jesu lidelseshistorie, der jo ligeledes udpensler en lang torturscene. I modsætning til de to førnævnte er denne relation imidlertid parodisk. Mange små og store træk i Kafkas fortælling alluderer til passionsberetningen. Officerens vasken hænder først i forløbet og overvejelserne hos den dømte sidst: "Var det sandhed?" (2008a: 145) spiller på temaer forbundet med Pontius Pilatus, hvis kone har en rolle, som minder om den, der tilskrives den nye kommandants damer. Den varme risgrød til den dømte erindrer parodisk om den eddikesure vin, der tilbydes Jesus. Vigtigere er strukturligheden i den rituelle skandering af det lange torturforløb med vendepunktet i den sjette time: "Hvor stille bliver manden ikke i den sjette time! Selv den tåbeligste kommer til forstand." (2008a: 135). "Hvor vi dog alle optog det forklarede udtryk fra det martrede ansigt [...]" (2008a: 139). Som den bibelske passion ender den kafkaske beretning med (en profeti om) genopstandelse: "Det er profeteret at kommandanten skal opstå efter et bestemt antal år og fra dette hus anføre sine tilhængere til en generobring af kolonien. Tro og vent!” (2008a: 150). I begge tilfælde har graven været bevogtet, men mens bevogtningen af Jesu grav ikke virkede, er officeren hidtil blevet forhindret $i$ at grave den gamle kommandant op.

En vigtig dimension af "I straffekolonien" er således et fremmedgjort, satirisk billede af en kultur, der har en langt udtrukken scene med pinsel til døden som sit vigtigste åbenbaringssted, sit sakrale centrum.

\section{Apparatets tre dele. Den gamle og den nye kommandant}

Det ejendommelige apparat, der præsenteres i fortællingens første sætning, og som ikke har noget modstykke hos Mirbeau, kan opfattes ret bogstaveligt. Klaus Wagenbach fremhæver Kafkas professionelle kendskab til farlige maskiner og de skader, de kan forvolde, som højtstående funktionær i "Arbeiter-Unfall-Versicherungsanstalt für das Königreich Böhmen in Prag”. Både Wagenbach og Hartmut Binder nævner desuden, at Kafka havde set talrige skræmmende apparater på de mange kursteder 
og sanatorier, han allerede i 1914 havde besøgt, bl.a. i Erlenbach ved Zürich og Riva ved Gardasøen. Som Ib Johansen gør opmærksom på, kan genstanden også ses i forlængelse af de sindrige morderiske maskiner, der er hyppigt optrædende ingredienser i 1700- og 1800-tallets gotiske skræklitteratur og fantastiske fortællinger. ${ }^{9}$

Efter min opfattelse ligger apparatets hovedbetydninger på et andet plan. Det kan man nærme sig gennem Oswald Spenglers Untergang des Abendlandes (Vesterlandets undergang, oversættelse i uddrag ved Mogens Boisen (Spengler 1962)). Dette indflydelsesrige historiske værk forelå i en nedskrevet version ved udbruddet af Første Verdenskrig, blev gennemarbejdet 1914-17, udkom i en første udgave 1918 og i den endelige 1922. Det er således samtidigt med "I straffekolonien". Mellem Spengler og Kafka kan der ikke have foreligget nogen form for påvirkning (slet ikke før 1918). Derimod ekspliciterer Spengler som samtidig inden for samme kultursfære et grundbillede af det traditionelle samfund, som jeg vil sandsynliggøre, at også Kafka forholdt sig til. Grundbilledet var fælles, selv om deres forhold til det var vidt forskelligt. Spengler omfattede det med megen veneration, Kafka udstillede det fremmedgjorte apparat med ætsende satire.

Spengler opererer med tre 'urstænder', hvilket han illustrerer med et citat fra Freidanks tidlig-gotiske digt "Bescheidenheit":

64 Got hât driu leben geschaffen

Gebûre, Ritter, phaffen. ${ }^{\text {IO }}$

Bønderne er ganske vist ikke en rigtig stand, som er 'i form', men en slags naturgrundlag, der omtales i kollektivformer som 'Gebure' eller nyere 'Bauerntum'. Om forholdet mellem de tre urstænder skriver Spengler bl.a.:

4 Den indre, følte afstand er så skæbnebestemt og mægtig, at ingen forståelse danner bro. Had vælder opad fra landsbyerne, foragt stråler tilbage fra borgene. Hverken ejendom eller magt eller erhverv har skabt denne afgrund mellem de "driu leben". Den er af metafysisk natur. (Spengler 1962: 321). Adelsmanden lever i en verden af kendsgerninger, præsten $i$ en verden af sandheder; den første er en kender, den anden erkender, den første er et handlings-, den anden et tankemenneske. Aristokratisk verdensfølelse er helt igennem takt, den præstelige forløber helt igennem i spændinger. (322)

Adel og gejstlighed er stænder 'i form'. Om epoker præget af 'form' siger Spengler: "Jo dybere formen er, desto strengere og mere frastødende er den. For den, der ikke tilhører den, virker den som slaveri; de, som tilhører den, behersker den med fuldkommen frihed og lethed" (320).

"I straffekolonien" har som centralbillede et apparat, der består af tre dele: den øverste kaldes tegneren, den midterste, skarpe og bevægelige del betegnes som harven, og den underste sengen. Der er ligeledes tre hovedpersoner: den forskningsrejsende, officeren (dommer og bøddel) og den dømte (en indfødt tjener, som har standsfæller i soldaten og de fattige, udslidte arbejdere i tehuset). Maskinens dele og hovedpersonerne spejler hinanden som repræsentanter for de tre urstænder: de intellektuelle, krigerne (adelen, officersstanden) og folket. Statsapparatets dele 
fungerede engang imponerende sammen som et hele under den gamle kommandant.

Franz Joseph den Første - som Franz Kafka blev opkaldt efter ${ }^{\mathrm{II}}$ - var fra 1848 kejser af Østrig og fra reformen i 1867, hvor Det østrig-ungarske Dobbeltmonarki blev oprettet, tillige konge af Ungarn til sin død i 1916. I hans tid hang det store multinationale og -kulturelle rige nogenlunde sammen og oplevede megen udvikling og mange intellektuelle triumfer. Samtidig sad det fast i bureaukrati, undertrykkelse og politisk stagnation. Riget led gentagne tab i blodige krige: nederlagene til det nye Italien med slaget ved Solferino i 1859 som det vigtigste; herefter nederlaget til Preussen i den tysk-østrigske krig i 1866. Voldsomme tragedier ramte kongehuset selv. Kronprinsen, ærkehertug Rudolph, begik sammen med sin elskerinde Mary Vetsera selvmord i 1889 på slottet Mayerling. Kejserinde Elisabeth blev myrdet af en anarkist i 1898. Tronfølgerparret, ærkehertug Franz Ferdinand og Sophie, blev myrdet af en serbisk nationalist i Sarajevo i 1914, hvilket udløste Første Verdenskrig. Ved krigens udbrud kendetegnede en uhyrlig ophobning af uløste indre spændinger Det østrig-ungarske Dobbeltmonarki.

Under den gamle kommandant var man trods alt så indlevet i systemet, at skønt det fungerede som en pinefuld ofring af folket (der ofte talte et andet sprog end herskerne, f.eks. et slavisk sprog), kunne magthaverne hævde, at også folket kunne se en forløsende patriotisk mening i sin egen opofrelse. Den enevældige gamle kommandant programmerede selv det budskab, den lovtekst, som derefter gennem tegneren (præsterne, bureaukratiet, de intellektuelle) blev overført til harven og pint ind i kroppen på folket, der var kneblet og fastspændt i sengen. Men det var på ingen måde ubetvivleligt, om offeret forstod det specifikke budskab. Dels var ganske lidt tekst pakket ind i et sådant utal af omsvøb og forsiringer, at selv senere tiders intellektuelle næppe kunne tyde det. Dels var budskabet skrevet i et sprog, som ofrene sjældent forstod. Hvis noget har været forstået, har det højest været selve den ubetingede skyld, folkets indiskutable pligt til lydighed og lidelse.

En side af magtapparatet var dets yderst synlige, ærkekonservative romersk katolske orientering, skønt jøder, muslimer, russisk/græsk ortodokse og protestanter fandtes og blev tålt i dette halvfeudale konglomerat af folkeslag, sprog og kulturer. At magt og (katolsk) kristendom var nært forbundne, sprang (springer) ikke mindst i øjnene i Prag. Nedkæmpelsen af den bøhmiske husitter-bevægelse blev slået fast gennem en overrepræsentation af katolske barokkirker, karakteriseret af en særligt påfaldende version af den barokke kombination af pragt og udpenslet lidelse. Kafkas jødiske baggrund, men også hans indstilling som sekulariseret intellektuel, kan have gjort det nærliggende at omfatte den magthavende kristendom under den gamle kommandant med et 'fremmed blik', at underliggøre den kristne pinselsåbenbaring og forbinde den med undertrykkelsen af den jævne befolkning.

Harven, den bevægelige og skarpe del (militær og politi), et teknisk mesterværk, pinte offeret til døde efter alle kunstens indviklede regler. Men på det seneste er denne del svækket noget af den omsiggribende humanisering: den dømte bliver forkælet med et sidste måltid, og den ætsende væske, der bed ekstra i offeret, er blevet afskaffet. For sengens vedkommende bandt og kneblede den offeret. Men nu er de remme, der binder offeret på hænder og fødder godt mørnede, og den filtstump, der 
skal forhindre offeret i at klage sig, er til at brække sig over, da det er længe siden, den er blevet fornyet.

I det hele taget er apparatet, statsmaskinen, godt nedslidt. Især er der problemer med tegneren, altså de intellektuelle; de gør modstand og hyler op, så man næppe kan få ørenlyd, og det er svært at få erstatning: "Desuden er der et tandhjul i tegneren, der er slidt helt ned; det hviner meget højt, når det kører; så kan man næsten ikke gøre sig forståelig; reservedele er desværre vanskelige at opdrive her" (Kafka 2008a: 129). Da officeren efter en del forberedelser begynder at demonstrere apparatets fortræffeligheder, gør tegnerens hvinende hjul meget til at ødelægge oplevelsen, og officeren truer af det: "Havde hjulet ikke hvinet, ville det være herligt. Officeren truede med næven af det forstyrrende hjul, som om det var en overraskelse for ham, bredte derefter armene undskyldende ud mod den rejsende og klatrede hurtigt ned for at iagttage apparatets arbejde nedefra" (2008a: 135).

Under det videre henrettelsesforløb bryder maskinen gradvist sammen. En af remmene, der skal fastholde den dømte, brister og må erstattes med en lænke. Den dømte brækker sig ud over det hele - som følge af "den nye, milde retning”: “"Det er alt sammen kommandantens skyld!" råbte officeren og ruskede ude af sig selv i de forreste messingstænger, "min maskine bliver lige så uren som en stald" (2008a: 137). De undergivne er i det små udisciplinerede: Den dømte snapper før tiden efter risgrød, og soldaten tager af den med sine snavsede hænder. Det er dog i tegneren, den intellektuelle del, at apparatets sammenbrud - da officeren endog mod maskinens bestemmelse har anbragt sig selv i offerets position - sker først og er mest synligt og dramatisk:

64 Da hørte han en lyd oppe i tegneren. Han så op. Var der alligevel et tandhjul der forstyrrede? Men det var noget andet. Langsomt løftede tegnerens låg sig og klappede så helt op. Takkerne fra et tandhjul viste sig og hævede sig, snart kom hele hjulet til syne, det var som om en eller anden stor magt pressede tegneren sammen så der ikke længere var plads til dette hjul; [...] Men straks steg et andet hjul op deroppe, det blev fulgt af mange andre, store, små og næsten ikke til at skelne fra hinanden, der skete det samme med dem alle, hele tiden troede man, at nu måtte tegneren da efterhånden være tom, så kom en ny, særlig talrig gruppe til syne, steg op, faldt ned, rullede i sandet og lagde sig. Dette forløb fik den dømte til at glemme den rejsendes ordre, tandhjulene gjorde ham fuldkommen henrykt, han ville hele tiden fange et, forsøgte samtidig at få soldaten til at hjælpe sig, 
men trak forskrækket hånden tilbage, for straks kom der et andet hjul som, i hvert fald lige når det kom rullede, gjorde ham bange.

Den rejsende derimod var dybt foruroliget; maskinen faldt tydeligvis fra hinanden; dens rolige gang var en illusion; han følte det som om han nu måtte tage sig af officeren, da denne ikke kunne sørge for sig selv. (2008a: 148f.)

Lad os se på persontegningen og forholdet mellem de tre hovedpersoner. Den forskningsrejsende er synsvinkelperson. Den rolle egner han sig til, da han repræsenterer de intellektuelle i almindelighed: han iagttager med et 'fremmed blik' kulturer og sammenligner dem; han søger at erkende og forholde sig til sandheder ud fra en humanistisk grundholdning. Og hvordan tager forholdet til de to andre 'urstænder' sig ud i hans optik?

Officeren er gammeldags og patriotisk, holder sig til sin varme, stive, upraktiske uniform, fordi den knytter ham til fædrelandet. Han er velformuleret, taler kyndigt, teknisk og engageret med den forskningsrejsende på et sprog, de begge forstår. At det gamle system er på sammenbruddets rand, forsøger han først at fortrænge, også sin dybe skam over dets nedslidte tilstand. For den forskningsrejsende står han som en mere og mere isoleret forsvarer af et forældet og grusomt system, og hans stadigt mere tryglende appel om støtte til dette system, ${ }^{\mathrm{I} 2}$ som alene giver hans tilværelse mening, fremmedgør og frastøder blot. Skønt officeren har truet af de mislyde, der udgår fra de intellektuelle dele af apparatet, er moralsk accept fra samme kant alligevel afgørende for ham. Da officeren føler, at han har mistet den intellektuelles støtte, altså legitimiteten i sin lov, agerer han konsekvent, som en handlingens mand. Han forsøger at gøre sig til apparatets offer på kavalermæssig vis, klæder sig nøgen, bryder sin kårde og lægger sig på offerets plads i pinebænken. Men hans undergang sker hurtigt, brutalt, uden nogen forløsende virkning, og uden at den rejsende kan gøre noget: "Den rejsende ville gribe ind, muligvis få det hele til at standse, det var jo ingen tortur, sådan som officeren forsøgte at opnå det, det var direkte mord" (2008: 149). Med et stort spiger gennem kraniet hænger officerens lig obskønt til skue i den sammenbrudte maskine.

Den østrig-ungarske hær var enorm og militærudgifterne astronomiske - officeren hos Kafka indrømmer, at han tidligere "nærmest ødslede" (2008a: 136) med ressourcerne. Meget forsvandt i slendrian, korruption og dybt forældet tænkning. Således var en hovedvåbenart et kæmpemæssigt rytteri med flotte, farvestrålende uniformer. Straks fra Første Verdenskrigs begyndelse led de østrigske hære det ene eklatante nederlag efter det andet til de undertippede russiske og serbiske armeer. De flotte ryttere blev mejet ned i tusindtal med moderne maskingeværer, bl.a. af engelsk import: "ingen tortur [ ...] direkte mord"! Jeg minder om den "bedrøvelse over de østrigske nederlag", Kafka noterer i dagbogen den 13. september.

Offeret, den indfødte tjener, opnår sin frihed gennem en kombination af apparatets nedslidning og den rejsendes humane indgriben til hans fordel. Mellem ham og den forskningsrejsende er der før som efter omvæltningen en afgrundsdyb kulturkløft, og de forstår ikke hinandens sprog. Folkets mand fremtræder med en hundsk opførsel: ved pludselige provokationer farer han op og truer med at æde sin overordnede; ${ }^{\text {I3 }}$ ellers er han søvnig i det; han er let at tæmme, hundsk hengiven. På 
omvæltningen reagerer han med et hævntørstigt grin. Og han kaster sig over den intellektuelle som en ny autoritetssubstitut. Men med de lidelser, der under en ny orden venter ham og hans lige (havnearbejderne) - og med de skuffende erfaringer med de intellektuelle, der tegner sig - er det meget tænkeligt, at han vil længes tilbage til den gamle orden og arbejde for dens genrejsning. Det er svært at afgøre for den forskningsrejsende.

Hvilken orden repræsenteres så af den nye kommandant? Selv om det gamle system ikke er afskaffet ved en klar reform, men endnu tolereres, er det en 'ny mild retning', der bliver sat igennem i den forstand, at vægten flyttes fra den rituelle pinefulde ofring til opslidende arbejde med havnebyggeri og lignende. Fremskridtet for folket er relativt. Den nye ordens spor ses på gæsterne i tehuset, hvor den gamle kommandant ligger begravet: "Det var sandsynligvis havnearbejdere, stærke mænd med korte, skinnende sorte fuldskæg. Ingen af dem var iført jakke, deres skjorter var lasede. Det var fattige, ydmyge ${ }^{14}$ folk" (2008: 150).

Industriproduktionen i Østrig-Ungarn blev tredoblet 1880-1913:

46 Østrig var teknologisk førende inden for bryggeri-, glasværks-og tekstilindustrien, men i takt med våbenkapløbet blev sværindustrien den vigtigste sektor, særlig i Steiermark og Bøhmen-Mæhren. Selv om de tjekkiske lande i 1910 kun tegnede sig for 36\% af Zileithaniens [den østrigsk-tjekkiske del af dobbeltmonarkiet] befolkning, udgjorde de $65 \%$ af industriens arbejdsstyrke og 68\% af maskinkraften; Skodafabrikkeme blev hovedproducent af maskiner og våben. (Encyclopædi 2001, bd. 20: 572)

Som bosat i Prag befandt Kafka sig i industrialiseringens centrum og som ansat i "Arbeiter-Unfall-Versicherungsanstalt für das Königreich Böhmen in Prag" var han helt tæt på dens bagside i form af de mange, frygtelige arbejdsulykker, det var hans arbejde at tage stilling til. Han havde også hjulpet sin svoger Karl Hermann med at oprette en asbestfabrik og optrådte netop i efteråret 1914, da svogeren var indkaldt til militærtjeneste, som vikarierende leder af fabrikken, hvad der belastede ham meget. Som bl.a. Wagenbach har fremhævet, var Kafka en af de få pragertyske forfattere, der var helt a jour med den industrielle udvikling.

Da "I straffekolonien" skulle udgives i 1917, gjorde Kafka i et brev til sin tyske forlægger Kurt Wolff opmærksom på, at han var utilfreds med fortællingens slutning. Forinden, i august 1917, havde han gjort udkast til alternative slutninger, der dels udmaler det hårde (vej)arbejde under den nye kommandant, dels udpensler den rejsendes følelse af skyld over sin andel i officerens død, en skyldfølelse, der i en version forvandler ham til en hund. Men den gamle slutning blev dog stående.

\section{"til dels fuldstændig begribelse af min situation"}

Med det foregående vil jeg hævde at have udfoldet nye betydningsdimensioner og dermed bidraget til en mere fuldstændig begribelse af, $h$ vorledes "I straffekolonien", med Jost Schillemeits ord, udvikler "en lignelsesagtig-allegorisk, dobbeltbundet fortælleform", der "har med forfatterens samlede åndelige og sjælelige "situation" at gøre og er bestemt til at afklare den" (Schillemeit 2004: 357). 
Det er ikke så vanskeligt at se de selvbiografiske sider af denne kortlægning på baggrund af den personlige rystelse, Kafka havde gennemgået, da den historiske rystelse med krigsudbruddet og Østrig-Ungarns skæbne under de første krigsmåneder kom til. Fortællingens særegne 'analyse' af Dobbeltmonarkiets klasser, magtforhold og statsapparat mellem to kommandanter har imidlertid været stærkt underbelyst. Medens Mirbeau-relationen har været kendt som en alment-samfundskritisk parallel, har der ikke været blik for, hvorledes Kafka har omfunktioneret billeder og retorikker herfra til en efter min opfattelse langt skarpere og mere konkret samfundskritik.

I forholdet mellem de intellektuelle og folket har Dostojevskij været et vigtigt orienteringspunkt for Kafka i 1914. Der er problemer både i den gængse opfattelse, der blot ser Kafka i forlængelse af Dostojevskij, og i den betydeligt rigtigere opfattelse, jeg gjorde gældende i min artikel "Processen i Kafkas anti-digtning", der gør opmærksom på elementerne af parodi på og opgør med Dostojevskijs idealisering af 'folket'. Begge opfattelser må modificeres af det faktum, at Dostojevskij flere steder, ikke mindst i det berømte brev til broderen efter frigivelsen fra tugthuset, fremførte diametralt modsatte oplevelser og opfattelser. Min artikel påpegede med rette den skepsis over for folket, ikke mindst de tendenser, det kunne ligge under for i fremtiden, der kommer til udtryk i Kafkas skrifter fra efteråret 1914 og ikke sjældent har taget form af en underminering af en dostojevskijsk idealisering af folket som moralsk instans; men overså, hvorledes Kafka, ikke mindst i "I straffekolonien", også kunne spejle sig i Dostojevskijs oplevelse af, at intellektuelle, der bogstavelig talt havde 'ofret sig' for folket, i det faktiske møde med selvsamme folk blev afvist, forhånet og forfulgt.

For relationen til Dostojevskij såvel som til Mirbeau er det afgørende imidlertid deres integrering i det totalbillede af klasser, magtforhold og statsapparat, der er involveret i kortlægningen af den intellektuelles situation. Som klasseanalytisk optik har Kafka anvendt den samme gruppering i tre hovedklasser, 'urstænderne', vi forefinder hos en så berømt og slagkraftig samtidig historiker som Oswald Spengler, uanset deres vidt forskellige udgangs- og sigtepunkter. Som genistreger i Kafkas sært fremmedgjorte litterære gestaltning betragter jeg den parallel mellem det statslige (tortur)apparats tre dele (tegneren, harven og sengen) og fortællingens tre hovedpersoner, der er påpeget i nærværende artikel. Hertil kommer fortællingens tolkning af den dramatiske historiske udvikling, hvor apparatets og de agerende personers tilstand og skæbne spejler hinanden.

Væsentlige forudsætninger for den historiske kompleksitet og præcision, som den vilde lignelsesagtig-allegoriske fremstilling paradoksalt nok rummer, er rimeligvis så forskellige faktorer som den udenforstående betragterrolle, Kafka reflekterer bekymret over i dagbøgerne, og den smertelige medleven i de for Østrig-Ungarn fatale krigsbegivenheder, der samtidig fremgår af hans notater; desuden vil jeg pege på Kafkas privilegerede adgang til indsigt i det østrig-ungarske statsapparat og den industrielle udvikling.

Den forskningsrejsende repræsenterer i høj grad Kafkas egen situation, men betragtes også udefra med megen (selv)ironisk distance. Han taler samme sprog som officeren, men deler på ingen måde værdier med ham. Han ser kritisk på den stive, upraktiske uniform og "har ikke megen sans for apparatet" (2008a: 127). Det tør 
siges. Som intellektuel betragter han illusionsløst den gamle kommandants orden som et apparat til ofring af folket, hvis rituelle kerne er at pine det ihjel. Derfor udgør de intellektuelle gruset i maskineriet, der er afgørende for apparatets sammenbrud, både i form af den rejsendes nej til officeren og i form af de hvinende mislyde fra tegneren, der munder ud $i$, at dens nedslidte tandhjul hopper af enkeltvis og i grupper. Officeren er ambivalent over for den intellektuelle, både truende (af det hvinende hjul) og tryglende for opbakning. Ubøjeligt brutal ved magten, men selvopgivende, da han mener at have tabt sin sag. Hans død, som besegler maskinens sammenbrud, er "direkte mord" uden katharsisk virkning, men bebyrder dog den intellektuelle med en vanskeligt håndterlig skyld.

Den intellektuelle gennemskuer folkets (forskellige) offerroller både under den gamle og den nye kommandant og ønsker at hjælpe det ud af dem. Men den rejsendes kontakt med fangen og soldaten er endnu dårligere end med officeren. De taler et andet sprog og ter sig spontant, naivt, undertiden opfarende dyrisk. Folket fremtræder som autoritetssøgende og upålideligt, potentielt nostalgisk tilbageskuende, reaktionært og farligt. Den samlede udvikling i årtierne efter det østrig-ungarske statsapparats sammenbrud viste desværre kun alt for godt, at denne bekymring ikke var grebet ud af luften. En overlevende (under)officer fra Østrig fik en nøglerolle i udviklingen af nazismen, der appellerede til den længsel tilbage til 'den gamle kommandant', som bl.a. var ret udbredt i en del folkelige lag.

Kortlægningen af den (jødiske) intellektuelles "situation", som den tegner sig i krigens første måneder, giver et tænderskærende satirisk billede af folkets lidelser under den gamle og den nye orden, af officerens meningsløse død og apparatets sammenbrud. Det munder ud i synet af en intellektuel på flugt, svært belastet af skyld - skyldfølelse over ikke at have villet hjælpe officeren; skyld over ikke at have villet påtage sig et ansvar for folket. Kafka havde det svært med denne slutning, men kunne ikke finde på noget alternativ. Implikationerne er: Hold dig udenfor, selv om det gør ondt! Stik af, mens tid er!

"I straffekolonien" afslører de uoverstigelige kløfter mellem samfundets hovedgrupper, der medførte apparatets sammenbrud og tegnede skidt for sammenhængskraften i fremtiden. Ikke mindst virker afstanden umådelig mellem de intellektuelle og de folkelige lag, hvilket givetvis hænger sammen med de sociale modsætningers besværlige overlejring med etniske, sproglige og nationale skillelinjer - samt ikke mindst manglende demokratiske erfaringer. Men alt taget i betragtning er "I straffekolonien" en fremstilling af den intellektuelles situation under en stor omvæltning med en bidsk samfundssatirisk indsigt og en god portion selvironi.

\section{Noter}

I En renommeret Kafka-forsker, der har haft ansvaret for den nye videnskabelige udgave af Der Prozess.

2 “'Ausssagen' über die eigene Zeit als solche, im Unterschied zu andere Zeiten, nicht 'Deutungen' der eigenen Zeit oder des eigenen 'Zeitalters', und zwar in den persönlichen Zeugnissen, den Briefen und Tagebüchern, ebensowening wie in den literarischen Texten. [I stedet domine- 
rer her] ein deutlich erkennbarer, wenn auch schwer genau definierbarer autobiographischer Grundzug" (Schillemeit 2004: 227).

3 Hvor det er muligt citerer jeg fra det danske udvalg (Kafka 1991), men henholder mig i øvrigt til den samlede tyske udgave (Kafka 1995, VIII), idet jeg bringer citaterne i egen oversættelse.

4 Samtidig er det mit mål seriøst at udbygge og på et væsentligt punkt korrigere den tolkning af "I straffekolonien", jeg fremlagde som led i artiklen "Processen i Kafkas anti-digtning" (Gemzøe 1772/74/82). Først og fremmest står min daværende opfattelse af Kafkas forhold til Dostojevskij til revision her, som det vil fremgå. Artiklen repræsenterer også mange års engagement i Kafka ved at være en omfattende videre bearbejdning af mit oplæg på et internt seminar om "Kafkas fortællinger" arrangeret af Center for Modernismeforskning ved Aalborg Universitet og afholdt på Klim Strandskole 23.-24.8. 2005, med aktiv deltagelse af Moritz Schramm, Claus Krogholm, Ib Johansen, Astradur Eysteinsson, Gorm Larsen og undertegnede.

5 Om anatomien/ den menippæiske satire, se Bachtin 2010: 129-165 og Gemzøe 1997: 249-254.

$6 \varnothing$-temaet er, i et noget andet perspektiv end her, taget op i Hadomi 1980.

7 Bemærk selvmodsigelsen! Sten Rasmussens oversættelse er ukorrekt: "14 dage, til dels med godt arbejde, fuldstændig forståelse af min situation" (Kafka 1991: 114).

8 Billedet af Dostojevskijs forhold til 'folket', som jeg især udfoldede i min artikel "Processen i Kafkas anti-digtning" i en relatering mellem Forbrydelse og straf og Processen er forenklet, idet det ikke tager hensyn til den negative erfaring med folket under Dostojevskijs tugthusstraf. I særlig grad har netop behandlingen af "I straffekolonien" derfor behov for revision, medens artiklens billede af de intertekstuelle relationer i tilknytning til Den bortkomne/Amerika, "En landlæge" og Processen er mere dækkende. Der er næppe grund til at kommentere de indlysende svagheder i den tidstypiske politiske skråsikkerhed, der kendetegner enkelte formuleringer, især i artiklens slutning.

9 Jf. Johansen 1983: 67f.

Io Note i bogen: "Gud har skabt tre slags liv: Bønder, riddere og præster. Bemærk kollektivforstavelsen "Ge" i Gebûre. O. a. (Spengler 1962: 321).

II Jf. Pawel 1992: 15. Skønt biografisk litteraturforskning altid står i fare for uholdbare kortslutninger mellem liv og værk, er den ofte en uundværlig tilgang til litteratur, der blot må relativeres og kontrolleres gennem andre tilgange. Jeg anerkender Pawels biografi som et af de nyere bidrag til Kafka-forskningen, der har inspireret mig mest.

I2 Jf. appellen fra Mirbeaus torturbøddel.

I3 Jeg minder om denne passage om 'folket' fra Dostojevskijs før citerede brev til broderen: "Dersom vi havde vist os i mindste måde eftergivende, havde de ædt os med hud og hår."

I4 Isak Winkel Holms generelt gode oversættelse er her på flere planer misvisende: "es war armes, gedemütigtes Volk” (1995, II: 176). Ikke ydmyge, men ydmygede, altså holdt nede og ydmyget af magthaverne. Ydermere henviser 'de fattige og ydmygede' til titlen på et af Dostojevskijs første værker, nemlig De ydmygede og sårede (1861). Læg endelig mærke til den upersonlige form ("armes, gedemütigtes Volk") - i lighed med "Gebure" eller "Bauerntum" hos Spengler.

\section{Litteratur}

Kafka, Franz (1995): Gesammelte Werke. Herausgegeben von Max Brod. Taschenbuchausgabe in acht Bänden. Herunder II: Erzählungen; VIII: Tagebücher 1910-1923. Frankfurt am Main: Fischer Taschenbuch Verlag 
Kafka, Franz (2008a): Fortællinger. På dansk ved Isak Winkel Holm, Villy Sørensen, Per Øhrgaard. Redaktion Isak Winkel Holm. København: Gyldendal

Kafka, Franz (2008b): Efterladte fortællinger. På dansk ved Isak Winkel Holm, Villy Sørensen, Per Øhrgaard. Redaktion Isak Winkel Holm. København: Gyldendal

Kafka, Franz (1991): "Mit liv er en tøven før fødslen”. Dagbøger i udvalg ved Sten Rasmussen. København: Hans Reitzels Forlag

Bachtin, Michail (2010 (1963)): Dostojevskijs poetik. Andra, reviderade upplagan. Gråbo: Anthropos Bibelen (1964), København: Det Danske Bibelselskab

Binder, Hartmuth (1975): Kafka-Kommentar zu sämtliche Erzählungen. München: Winkler Verlag

Burns, W. (1957): “In the Penal Colony': Variations on a Theme by Octave Mirbeau”, in Accent 17, s. $45-51$

Den Store Danske encyklopædi (2001), bd. 20, København: Gyldendal

Dostojevskij, Fjodor (1966): Dostojevskijs breve i udvalg I-II, Samlede værker, bind 23-24, København: Stig Vendelkærs Forlag

Gemzøe, Anker (1972): "Processen i Kafkas anti-digtning", in Poetik nr. 17, s. 25-57. Genoptrykt in Litteraturvidenskab (1974), Roskilde: RUC Forlag. Og genoptrykt in Alfons Höger, Søren Schou og Klaus Schulte (red.) (1982): Analyser af tysk litteratur. København: Forlaget Text \& Kontext

Gemzøe, Anker (2007): "Romanen på grænsen. Mann, Broch, Kafka - og Sørensen”, in Anker Gemzøe og Ernst-Ullrich Pinkert (red.): Deutschstunde: Tysk kulturimport i Danmark efter 1945, Wien: Praesens Verlag, s. 67-85

Gemzøe, Anker (1997): Metamorfoser i Mellemtiden. Studier i Svend Åge Madsens forfatterskab 1962 1986, København: Forlaget Medusa

Hadomi, Leah (1980): “The Utopian Dimension of Kafka's "In The Penal Colony"”, in Orbis Litterarum, vol. 35, s. 235-249

Heller, Erich og Beug, Joachim (red.) (1969): Dichter über ihre Dichtungen. Franz Kafka, München: Heimeran/ S. Fischer Verlag

Johansen, Ib (1983): "Kafka og det fantastiske”, in Essays om Kafka - 100 år, Århus: Sjakalens Beduinserie

Mirbeau, Octave (1929 (1899)): Le jardin des supplices, Bibliotèque-Charpentier, Paris: Fasquelle, Éditeurs

Pawel, Ernst (1992): Franz Kafka. Fornuftens mareridt. En biografi. På dansk ved Kirsten Jørgensen. København: Spektrum

Ruggierio, Vincenzo (2003): Crime in Literature. Sociology of Deviance and Fiction, London \& New York: Verso

Schillemeit, Jost (2004): Kafka-Studien, Göttingen: Wallstein Verlag Spengler, Oswald (1962): Vesterlandets undergang, København: Gyldendal

Wagenbach, Klaus (1975): Franz Kafka. In der Strafkolonie. Eine Geschichte aus dem Jahre 1914, Berlin: Verlag Klaus Wagenbach 